\title{
NOISE AS A RISK FACTOR IN THE PREPARATION OF USEFUL MINERAL SUBSTANCES
}

\author{
Irimia Alin, \\ National Institute for Research and Development in Mine Safety and Protection to Explosion - INSEMEX \\ Petroşani, City Petroşani, Country Romania, e-mail alin.irimia@insemex.ro
}

Sorin Simion,

National Institute for Research and Development in Mine Safety and Protection to Explosion - INSEMEX Petroşani, City Petroşani, Country Romania, e-mail sorin.simion@insemex.ro

Pupăzan Daniel,

National Institute for Research and Development in Mine Safety and Protection to Explosion - INSEMEX Petroşani, City Petroşani, Country Romania, e-mail daniel.pupazan@insemex.ro

Călămar Angela

National Institute for Research and Development in Mine Safety and Protection to Explosion - INSEMEX Petroşani, City Petroşani, Country Romania, e-mail angela.calamar@insemex.ro

Abstract: Noise from industrial activities is a major problem because of its noxious and its presence in all technological activities. The coal preparation activity from industry, in the presence of risks of exposure to noise, is affecting the health and safety of workers. Occupational hearing loss and deafness caused by exposure to noise at work are the most encountered illnesses occurring in the European Union. This paper examines the main sources of noise in coal preparation technological process and their effects on the human factor.

Key words: Noise, risk, occupational disease

\section{Introduction}

The implications of physiological, psychological and social of noise are known in the contemporary world, being one of the most widespread pollutants in the world. Unlike exposure to dust and chemical pollutants, which have greatly reduced the extent of mechanization and automation of production processes, not the same was done on noise exposure.

Masking effect of the voice or of different sound and verbal signals, in the course of work processes lead to efforts attention, tiring, decreasing efficiency of the activity.

Noise generates additional fatigue not only due to the difficulty of collecting verbal information (orders, orders) or by voice overuse especially through brain overload.

Noise issues are unquestionably economically importance and, in some cases decreased work capacity reaching up to $60 \%$, particularly intellectual work is affected. The negative influence on the efficiency and effectiveness at work can be illustrated as follows: general industrial efficiency is $25 \%$ higher in quiet jobs compared to the noisy, the errors due to the noise are $70 \%$ of rejects in the electronics industry, $29 \%$ of accounting errors.

Noise is a "by-product of technology metabolism" as one of the most important factors of discomfort for personnel working in the coal preparation processes.

The development of modern technology by increasing power and speed of working machinery contributed to the diversification and increased sources of noise and vibration, and thus to increase the number of people exposed.

Noise is one of the most important industrial emissions that generate hazards to health of workers are forming harmful factors arising from damage and / or malfunction of working equipment. [1]

Industrial activities carried out in the workplace in the presence of noise risks are affecting the health and safety of workers in the preparation of minerals industry.

By stimulating measures for the improvement of health and safety at work, were developed specific guidelines regarding health and safety of workers. 


\section{The purpose of noise measurement in the preparation of minerals}

The preparation technological process is performed using selection operations, sorting, washing, transport, process air compression and processing operations and mass separation of ore mining machinery and equipment to be used with high level noise generators. [4]

To improve health and safety conditions at work and achieve the objective of reducing noise exposure should consider the following general principles relating to:

- Noise related risk assesment, carried out by competent people or departments;

- Prevention of occupational risks;

- Health and safety at work;

- Elimination of risk factors for injury and occupational disease;

- Information, consultation, balanced participation in accordance with national legislation and / or practice and training of workers and their representatives.

- check-up, in order to determine whether there have been some changes in the work process, to be followed by enacting of amendments within the assessment and control measures. [ [4]

\section{Hearing loss according to sound level}

If the ear is exposed to high levels of noise for a short period, a ear sensitivity test carried out immediately afterwards, shows a slight hearing loss known as temporary deviation threshold of hearing. Hearing threshold is the lowest sound pressure level which can be detected by the subject and it can grow up to $20 \mathrm{~dB}$ at certain frequencies, even after a relatively short exposure. The sound should be much louder than it was before exposure to be heard afterwards. Fortunately, the phenomenon is temporary, any permanent deviation threshold is too low to be measured.

If exposure periods are relatively short, and the intervals between them are long permanent effects are not significant. A large number of people working in technological processes where noise levels are always high and when the exposure occurs for 8 hours a day, year after year, the effects are not temporary. It develops a permanent hearing loss which is sufficiently severe as to make it difficult for normal conversation, and then get to chronic disease. Damage becomes permanent and irreversible in this phase, and any "rest" will not lead to a significant rebound.

Permanent damage begins, as the temporary with decrease in sensitivity around $4 \mathrm{kHz}$ frequency and with increasing exposure time, the deviation becomes larger and gradually extends down to include the lower frequencies (fig. 1). The frequency content of the noise with the type thereof (for example pulse and non-pulse character) may also be a disturbing factor.

Exposure to loud noise for a long time trigger the body's protective mechanisms against hazards, these mechanisms manifested by following vegetative reactions: hypertension, tachycardia, skin vessels constrict, increasing metabolism, increasing muscle tension. Noise-induced hearing loss is recognized by the World Health Organisation as "the most common and irreversible industrial disease". Hearing loss, besides it can stop a person working at full capacity, it can destroy social life, isolating it from the community. 
Figure.1. Evolution of hearing loss due to noise exposure

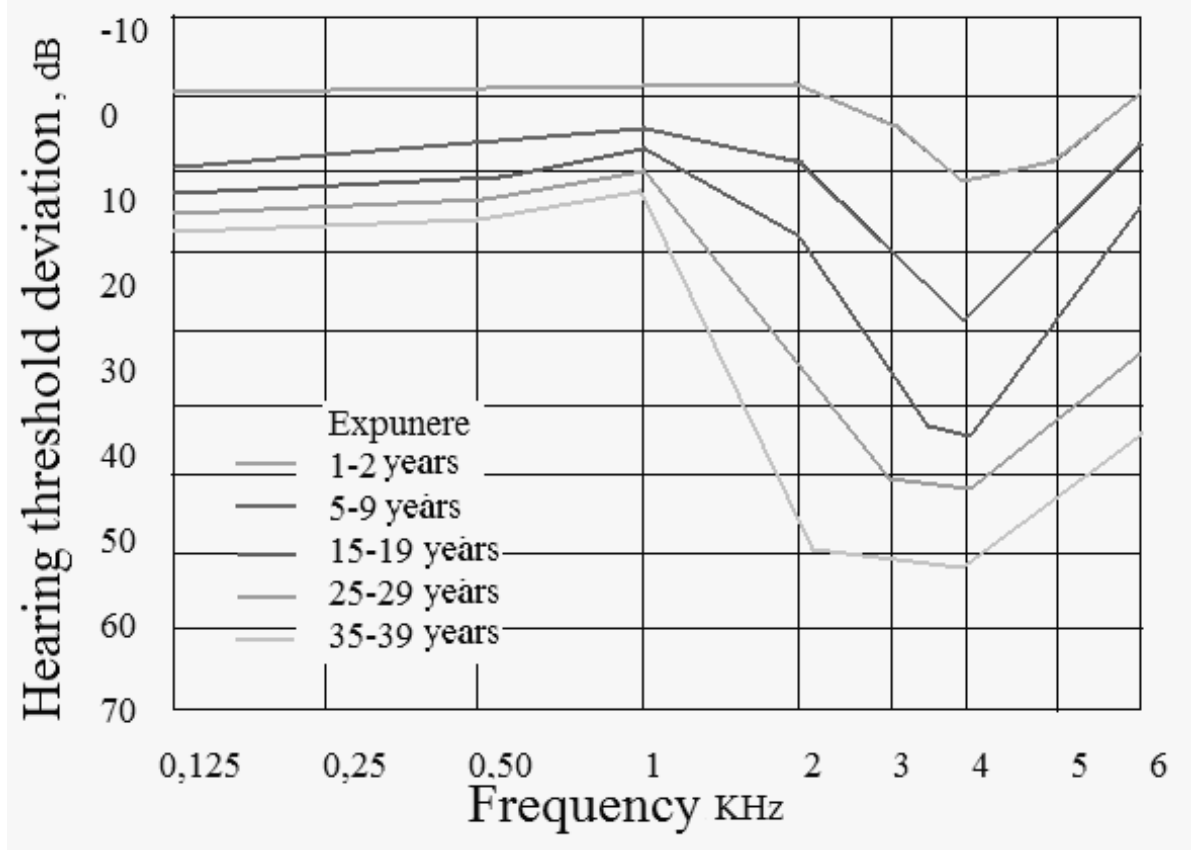

\section{Presenting the particularities of noise measurements in the preparation of useful mineral substances}

Noise emitted in the coal preparation technological processes have a continuous nature (pneumatic energy production system, tape transport, washing, floatation, breakdown) or flashing (while loading unloading wagons, funicular, etc..). [3]

Each noise source is characterized by acoustic power which depends on external factors such as distance, orientation receiver, temperature and velocity gradients in the propagation medium.

Particularities of preparation work is characterized by two aspects:

- -Harmful effects of physiological noise;

- -Ensuring that the exposed staff perceive safety signals (start flow lanes, turning off the funicular, etc.).

Noise levels produced by the plant and machinery used in the preparation of mineral substances include all types of noise including impulse.

Noises in the process of preparation of mineral substances are among the most numerous on the human body, afecting both hearing and othrt organs, for example leading to increased blood pressure, loss of visual acuity. Depending on the intensity of the of noise, there are several types of harmful effects on humans, namely:

- The effect of masking;

- Auditory fatigue;

- Acoustic trauma;

- Acute hearing loss;

- Occupational deafness;

- Effects of noise on the nervous system.

In the mineral substances preparation processes most appropriate methods for combating of noise from existing sources consist of active and passive protection measures.

The purpose of noise reduction is to achieve optimum acoustic comfort at an affordable price, without affecting other health and safety at work measures. Concept system against noise is generally a compromise between acoustic performance and cost price and musn't bring in new risks.

Modern methods of noise combating pursue three goals:

- A technical purpose for new installations and processes more silently;

- A social purpose by removing noise noxa affecting workers;

- A medical purpose such as protecting health of workers from complex effects caused by noise noxa. 


\section{Equipment used}

For direct measurement of sound pressure levels equivalent continuous A-weighted, integrated sonometers used meet the requirements of IEC 804, they are calibrated both before and after determinations. Calibration is required having quality results, also contributing to increased confidence in the accuracy determinations.

Sonometers used are made byBruel \& Kjaer Danish company. They are equipped with filters of one octave or $1 / 3$ octave pass band width.

Figure 2. Analyzer Type 2250

Figure. 3. Acoustic Calibrator Type 4231
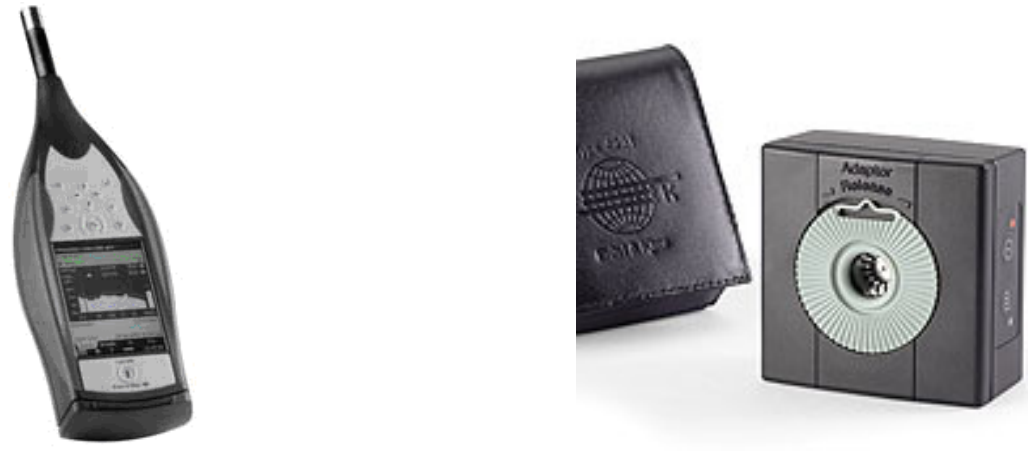

Type 2250 noise analyzer is used for individual measurements or series of measurements for laboratory and field analysis.

Measurement of sound pressure to determine the A-weighted sound exposure and / or level equivalent continuous A-weighted sound pressure were performed with the microphone placed in the position (s) occupied (filled) normally by the head worker.

If a worker was required to be present or to move around, the microphone was positioned $0.10 \mathrm{~m}$ $\pm 0.01 \mathrm{~m}$ from the entrance to the ear canal that receives high value weighted sound exposure sound pressure level or equivalent continuous a-weighted. [5]

Important details of the measuring apparatus and the conditions prevailing during measurements must be recorded and archived for reference [5]. In reporting the results of measurements, it includes an estimate of the overall uncertainty of the measurements, taking into account the influence of factors such as measurement equipment; microphone; number of measurements; variation in time and space of the noise source.

The minimum requirements for the protection of workers from risks to health and safety arising or likely to arise from exposure to noise and in particular the risk to hearing, apply to all activities in which workers are or may be exposed through their work, the risks arising from noise provided for in national legislation transposing Directive 89/391 / EEC applies to all activities without prejudice to more stringent and / or specific.

The physical parameters used as risk predictors, have the following meaning:

- peak sound pressure $\left(\mathrm{p}_{\text {peak }}\right)$

- daily noise exposure level $\left(\mathrm{L}_{\mathrm{EX}}, 8 \mathrm{~h}\right)$ defined in the standard SR ISO 1999:1996;[6]

- weekly noise exposure level $\left(\mathrm{L}_{\mathrm{EX}, 8 \mathrm{~h}}\right)$

\section{Results achieved}

Noise measurements were made at each stage of preparation. In table 1 are the results of measurements performed on the main media noise generating equipment used in the preparation of mineral sbstances [2].

Table 1

\begin{tabular}{|c|c|c|}
\hline $\begin{array}{c}\text { Crt. } \\
\text { pos }\end{array}$ & Worckplace & $\begin{array}{c}\text { Noise level } \\
\text { dB(A) }\end{array}$ \\
\hline $\mathbf{1}$ & SAG MILL & 92,2 \\
\hline $\mathbf{2}$ & BALL MILL & 92,3 \\
\hline $\mathbf{3}$ & FLOTATION HALL , PRIMARY INPUT & 90,1 \\
\hline $\mathbf{4}$ & FLOTATION HALL , CLEAN GETAWAY & 92,3 \\
\hline $\mathbf{5}$ & TRANSPORT DEPARTMENT,MINERAL & 97,1 \\
\hline $\mathbf{6}$ & BREAKER & 98,9 \\
\hline
\end{tabular}




\begin{tabular}{|c|c|c|}
\hline $\mathbf{7}$ & TURBO-BLOWER & 104 \\
\hline $\mathbf{8}$ & CHALK PREPAIRING STATION & 97,2 \\
\hline $\mathbf{9}$ & FILTERS HALL & 95,4 \\
\hline $\mathbf{1 0}$ & REUSED WATERS & 93,2 \\
\hline $\mathbf{1 1}$ & COMPRESSED-AIR PLANT & 94,8 \\
\hline $\mathbf{1 2}$ & CHALCK CRUSHER & 93,5 \\
\hline $\mathbf{1 3}$ & CHALCK MILL & 99,5 \\
\hline $\mathbf{1 4}$ & LABORATORY & 89,0 \\
\hline $\mathbf{1 5}$ & SELECTION & 104,6 \\
\hline $\mathbf{1 6}$ & FUNICULAR & 90,7 \\
\hline $\mathbf{1 7}$ & TMB CONVEYOR & 88,9 \\
\hline $\mathbf{1 8}$ & JIG WASHER & 99,4 \\
\hline $\mathbf{1 9}$ & ELEVATORS & 88,9 \\
\hline $\mathbf{2 0}$ & HYDROCYCLONE & 90,2 \\
\hline
\end{tabular}

The knowledge of noise intensity in the preparing processes of useful mineral substances allow to quantify effects on humans such as masking, auditory fatigue, noise trauma, acute hearing loss, deafness professional.

It is true that many noise combating problems are solved favorably by achieving a reduction of part of the sound power or sound pressure. There are situations where the correct solution is to change the frequency spectrum without necessarily reduce total sound level.

Figure 4 Simplified scheme of a noise combat system [2]

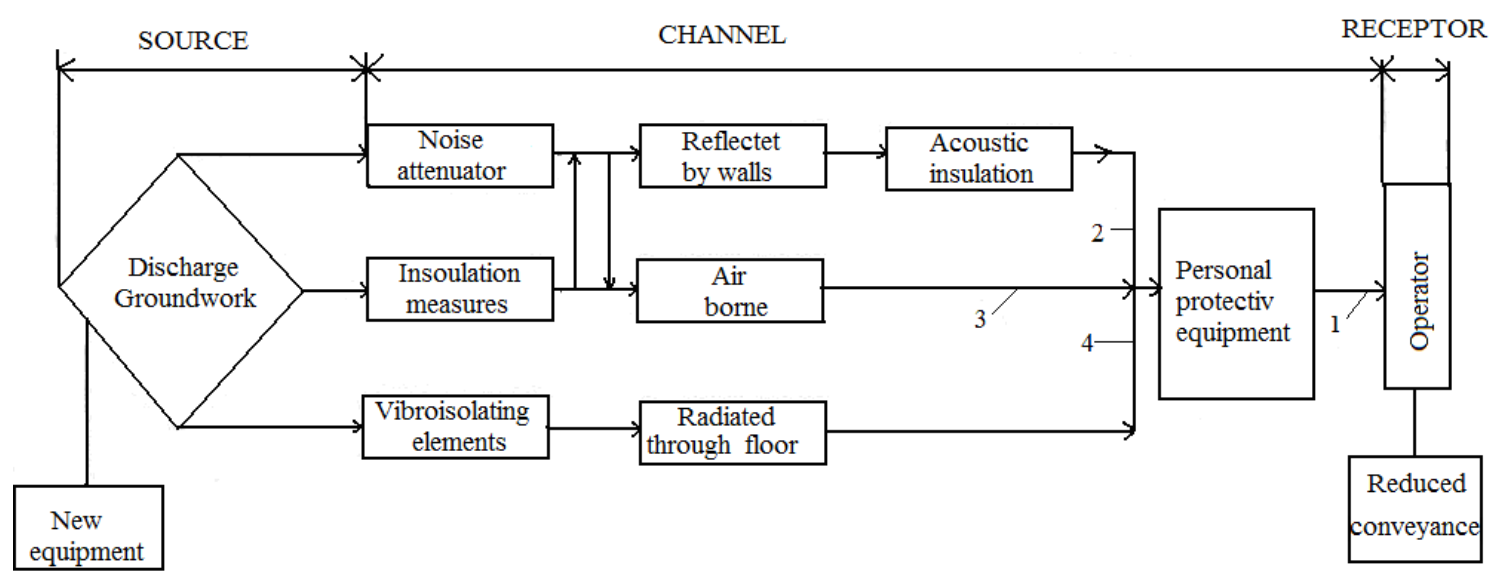

Noise in section 1 is the sum of contributions 2, 3 and 4, and noise abatement can be achieved through:

- Replace the machine with a new type silently;

- Installing near the machine of acoustic screens and change the controls;

- Mounting the machine on vibroinsulator elements;

- Use of individual hearing protection (ear protection internal or external);

- Limiting the time of operator exposure to noise.

Given the mentioned, include the following:

- noise abatement is a system problem;

-the purpose of combatting noise is to achieve an acceptable acoustic comfort at a price also acceptable;

- primary variables of the system are acoustic characteristics and the cost price;

- acoustic characteristics of the system determines ambient noise with its effects as the probability of damaging of hearing and loss speech intelligibility;

- -the design of the noise combat system is generally a compromise between acoustic performance and cost price.

The analysis of noise sources shows that optimal solutions to reduce exposure to noise noxa, are:

- application of active and reactive attenuators specific for each machines;

- replace the machine with a new type silently; 
- automation of technological processes and operators remove from default risk areas in terms of noise

- The installation near noise source of acoustic screens and change control elements;

- mounting the machine on vibroinsulator elements;

- use of individual hearing protection;

- limiting the exposure time.

\section{Conclusions}

From the above were materialized following conclusions:

- The values determined for the main sources of noise in the preparation of useful mineral substances are above the permissible limits by law respectively $87 \mathrm{~dB}(\mathrm{~A})$. For the limitation of the effects on health of workers are required technical and organizational measures;

- Lack of investment in mining affects the work of preparation. Upgrading activities require a great financial effort in terms of operators.

- The lack of markings on the noise emissions difficult to assess noise exposure of workers through indirect methods, respectively adopting optimal health and safety at work measures. Applying of marks on acoustic power equipment and information of workers lead to creating a safer working by reducing exposure to this noxa.

- Awareness of the risk of exposure of workers to noise noxa and irreversible effects of the pollutants on the auditory organ leads to lower reluctance on the use of personal protective equipment, which significantly reduces exposure to the contaminant or contaminant effects of the body.

- Regarding the use of personal protective equipment (external / internal type), there is a positive trend on their use by workers. Due to financial difficulties on upgrading / purchase of machinery and equipment quieter, the earplugs use still remains the easiest solution for the employer to reduce workers' exposure to the harmful effects of noise.

To check the effectiveness of methods for reducing noise, regardless of their nature (technical, organizational) is proposed the periodical monitoring of the level of noise to which workers are exposed because hearing loss is an irreversible disease that affects quality of life both at work and leisure.

\section{References}

- [1] A. DARABONT, Prevenirea şi combaterea zgomotului în industria minieră Bucureşti 1973

- [2] SIMION SORIN, SPIRIDON S., Prevenirea şi reducerea zgomotului emis de procesele industriale miniere, Editura INSEMEX , ISBN: 978-973-88753-0-2 / 2008

- [3] FAURE C: Controlul şi prevenirea zgomotului în instalaţiile de spălare şi preparare mecanică a cărbunelui Iulie 1978

- [4] *** Legea 319/2006 Legea securităţii şi sănătăţii în muncă

- [5] *** Directiva 2003/10/CE din 6 februarie 2003 privind cerinţele minime de securitate şi sănătate referitoare la expunerea lucrătorilor la riscuri generate de agenţi fizici (zgomot) [a şaptesprezecea directivă individuală în sensul art. 16 alin. (1) din Directiva 89/391/CEE]

- [6] *** SR ISO 1999:1996 Acustica. Determinarea expunerii la zgomot profesional şi estimarea deteriorării auzului 